\title{
Political Regimes and External Voting Rights: A Cross-National Comparison
}

\author{
Sebastián A. Umpierrez de Reguero ${ }^{1,2,3 *}$, Inci Öykü Yener-Roderburg ${ }^{4,5}$ and \\ Vivian Cartagena ${ }^{6,7}$
}

${ }^{1}$ Institute of Research in Social Science, Diego Portales University, Santiago, Chile, ${ }^{2}$ Institute of History, Leiden University, Leiden, Netherlands, ${ }^{3} \mathrm{Global}$ Citizenship Observatory, European University Institute, Fiesole, Italy, ${ }^{4}$ Department of Turkey Studies, University of Duisberg-Essen, Duisburg, Germany, ${ }^{5}$ Department of Political Science, Université de Strasbourg, Strasbourg, France, ${ }^{6}$ Casa Grande University, Guayaquil, Ecuador, ${ }^{7}$ The Permanent Committee for the Defense of Human Rights, Guayaquil, Ecuador

\section{OPEN ACCESS}

Edited by:

Johanna Peltoniemi,

University of Helsinki, Finland

Reviewed by:

Marco Lisi,

Universidade NOVA de Lisboa,

Portugal

Miroslav Nemčok,

University of Oslo, Norway

*Correspondence:

Sebastián A. Umpierrez de Reguero sebastian.umpierrez@mail.udp.cl

Specialty section:

This article was submitted to Elections and Representation, a section of the journal

Frontiers in Political Science

Received: 01 December 2020 Accepted: 27 January 2021

Published: 31 March 2021

Citation:

Umpierrez de Reguero SA, Yener-Roderburg IÖ and Cartagena V (2021) Political Regimes and External

Voting Rights: A Cross-

National Comparison.

Front. Polit. Sci. 3:636734.

doi: 10.3389/fpos.2021.636734
In this article, we analyze the nexus between political regimes and external voting rights. Using a global longitudinal dataset, we report that higher levels of inclusion and contestation bring higher probabilities that a state adopts and implements emigrant enfranchisement. Taking outliers from our quantitative assessment, we then further examine two liberal democracies, Ireland and Uruguay, and two electoral autocracies, Turkey and Venezuela. These country cases reveal three mechanisms that shed light on the strategic role of political elites in explaining the relation between political regime type and emigrant enfranchisement. First, the democracies under study show us that in certain contexts with a relatively large diaspora size and in which part of the political spectrum is hesitant about the political orientation of nonresident citizens, emigrant enfranchisement is neither necessarily promulgated nor implemented. Second, the autocracies illustrate that when the diaspora favors (or is perceived to favor) the incumbency, then external voting rights are extended; otherwise, third, they are withheld or limited for nonresident citizens.

Keywords: political regime, external voting rights, democratization, authoritarianism, emigrant enfranchisement, democracy

\section{INTRODUCTION}

Voting from abroad is broadly conceptualized as a set of procedures that enable nonresident citizens (emigrants) to partake in home-country elections and possibly stand as candidates (Nohlen and Grotz, 2000; Lafleur, 2013; Collyer, 2014a). It is a common practice globally, with more than 130 autonomous territories having promulgated emigrant enfranchisement (Allen et al., 2019). However, some democracies are still reluctant to grant electoral rights to their nonresident populations, whereas some autocracies bestow generous provisions to their emigrants that politically incorporate them in the demos. Considering the long-standing scholarly debate on democratization and democratic endurance from the mid-twentieth century to the present, we ask: to what extent does democracy predict the timing of the adoption and implementation of emigrant enfranchisement? If it is a main driver, what explains the deviant cases? In other words, why are some liberal democracies, such as Ireland and Uruguay, hesitant to enfranchise emigrants, while some electoral autocracies like Turkey and Venezuela still grant electoral rights to nonresident populations?

Existing literature has produced various explanations associating democratization, democratic endurance, and norm diffusion to external voting rights. First, the window-of-opportunity hypothesis-which refers to the crucial moment when countries democratize and, shortly thereafter, when they typically revamp their legal framework-is a plausible answer for why states enact, regulate, and apply such a provision of external voting rights (Rhodes and 


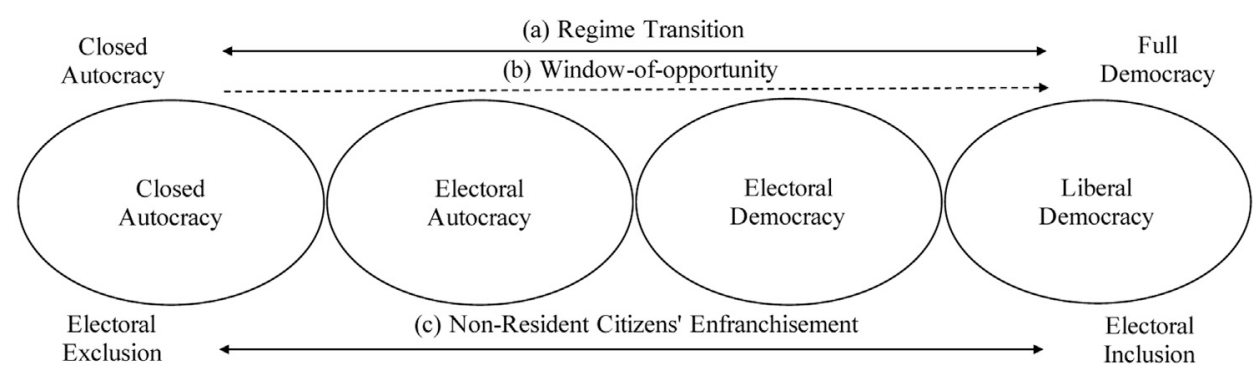

FIGURE 1 | Political regime vs. external voting rights. Source: authors' own elaboration based on Regimes of the World-the RoW measure (D) (v2x_regime) (see Lührmann et al., 2018).

Harutyunyan, 2010; Lafleur, 2015; Palop-García and Pedroza, 2019). Second, democratic norms as waves of emulation and diffusion appear to significantly correlate to emigrant enfranchisement. This is because globalization, along with technology and communication, has facilitated disseminating policies and practices around the world. Ease of communication allows neighboring countries to exchange information regarding their institutional experiments on external voting rights and on other migrant political transnational practices, such as dual citizenship (Turcu and Urbatsch, 2015). Third, political competition plays an increasingly important role in enfranchisement discussions. This might not only be explained by the fact that external voting can swing electoral results, but also because political competition may cause the incumbent and/or opposition parties to make electoral reforms and regulate external voting (Brand, 2010; Gamlen, 2015; Turcu and Urbatsch, 2020a; Wellman, 2020).

Considering previous academic appraisals, our theoretical argument supports the hypothesis that countries classified as democracies are more likely to adopt and implement external voting rights, as compared to autocracies. We disaggregated this nexus using a four-value variable of political regime and reporting that liberal and electoral democracy, as well as electoral autocracy, have a positive impact on emigrant enfranchisement, compared to closed autocracy. We also examine why some democracies withhold external voting rights, while some autocracies extend them, for various strategic state-level motivations. Refining the theoretical argument of Brand (2010) on autocracies, there are at least two reasons: 1) the countries enacted external voting rights when they had previously been democratic and currently prefer to generate more constraints to voting rather than reversing existing policies, and/or 2) they merely use external voting for their own benefit. For democracies that still fail to enact emigrant enfranchisement, external voting rights are a contested issue for homeland politicians, since they believe that emigrants' preferences can flip electoral results, either against them or in their favor.

Employing a regression-based nested analysis (Rohlfing, 2008), in which we combine a large- $\mathrm{N}$ analysis with a carefully selected set of case studies, we first evaluate whether democracy is a significant driver to emigrant enfranchisement and then attempt to determine why and how deviant cases behave differently. First, to examine if emigrant enfranchisement is associated with democratic regimes, we use a global longitudinal dataset (1896-2019) with countries that either have, or do not have, external voting provisions as of 2020 . Then, we dive deeper into four deviant cases (Ireland, Uruguay, Turkey, and Venezuela) to elucidate mesolevel mechanisms and state-led motivations for explaining their rationale of either granting or withholding external voting rights. Our conceptualization of external voting rights entails a clear-cut electoral eligibility of civilians and the rights of casting the vote from abroad. It thus excludes countries that only allow diplomatic and military personnel and/or nonresident citizens who travel during election day to their origin country, whether subsidized by the political elite (i.e., political parties and leaders) or willingly, to participate in homeland elections.

This article is structured as follows. First, we briefly discuss the relation between political regimes and emigrant enfranchisement. Second, we broadly compare emigrant enfranchisement in democratic vs. authoritarian regimes. Third, we unpack the mechanisms in four outliers-two democracies and two autocracies with counterintuitive outcomes-to examine how and why they have adopted and implemented external voting rights or decided to withhold such rights.

\section{THEORETICAL FRAMEWORK}

Despite most scholarly discussions on full political rights having traditionally linked them to democratic polity (e.g., LópezGuerra, 2005; Bauböck, 2015; Altman, 2020), emigrant enfranchisement is also present in authoritarian regimes (Østergaard-Nielsen, 2003; Brand, 2010; Collyer, 2014b). Empirical evidence suggests a probabilistic, rather than deterministic, logic that assumes democracies depict high levels of inclusion, whereas autocracies do not.

Relying on seminal contributions of democratic theory (e.g., Dahl, 1971; Dahl, 2008; Coppedge, 2012), such a puzzle can be explained by the necessary and sufficient conditions of being a democracy or autocracy. Political regimes can be classified by their levels of competition (or contestation) and participation (or inclusion) (Dahl, 1971). Whereas contestation refers to the procedures of political competition in free and fair elections, participation is mainly concerned with who partakes in the democratic decision-making process. Not every autocracy 
displays low inclusion, but, normatively, democracies should depict high degrees of both participation and competition (Clark et al., 2017).

Based on these scope conditions, four different types of political regimes can be classified: liberal democracy, electoral democracy, electoral autocracy, and closed autocracy (Lührmann et al., 2018). Liberal democracy is the regime most akin to Dahl's polyarchy, in which the rule of law and liberal principles are satisfied and the degrees of participation and competition are high. Electoral democracy displays high levels of inclusion and contestation but lacks some aspects of the rule of law and liberal principles. In an electoral autocracy, there is only one effective party, or the field of political competition is uneven despite de jure multiparty elections. Lastly, closed autocracies comprise all political regimes where neither de jure nor de facto competitive elections occur. Political inclusion can be high even in these cases, yet closed autocracies systematically violate liberal principles and rule of law (Lührmann et al., 2018), likely alongside also violating the political and civil rights of nonresident citizens.

Figure 1 shows a four-category relation between nonresident citizens' electoral inclusion and political regimes. It illustrates the different types of political regimes in circles and three lines indicating the following: (A) transitioning from one regime to another; (B) the window-of-opportunity hypothesis; and (C) the assumption that the odds of electoral inclusion for nonresident citizens is more likely to occur in a liberal democracy than in a closed autocracy.

Relying on the existing literature of regime transition and consolidation (e.g., Linz and Stepan, 1996; Bratton and Van de Walle, 1997), the continuum between democracy and authoritarianism may present different instances for emigrant enfranchisement. Preceding studies about the relation between democratization and external voting rights have been largely interested in a unidirectional conjecture (represented as a dashed line in Figure 1). As the window-of-opportunity hypothesis suggests, democratization is conducive to enlarging citizenship rights (Ramirez et al., 1997). It assumes that nonresident citizens-analogous to other historically marginalized collectives (e.g., women and ethnic minorities) excluded from franchise-may profit from a democratization process (Foweraker and Landman, 1999; Lafleur, 2015). Drawing on this assumption, Rhodes and Harutyunyan (2010) hypothesize that political competition encourages countries to enact external voting rights since it enables more actors to impact the policy-making process. In that sense, nonresident citizens' demands for voting rights are more prone to be heard in the domestic realm and supported by homeland political parties willing to capture overseas votes (Gamlen, 2015; ØstergaardNielsen et al., 2019; Burgess, 2020).

Considering the association between democratic norms and countries that have adopted and implemented external voting rights, scholars have further indicated the relevant role of democratization (e.g., Lafleur, 2015; Palop-García and Pedroza, 2019). Using the window-of-opportunity hypothesis, Rhodes and Harutyunyan (2010) correlate whether periods of democratic transitions establish a unique opportunity for creating several policies, such as dual citizenship and external voting. Although they found no significance in their quantitative assessment regarding the extension of emigrant enfranchisement, they highlight that democratic transitions are key in explaining the extension of citizenship regimes to nonresident citizens.

The window-of-opportunity hypothesis was particularly relevant in the Global South at the beginning of the third wave of democratization. In Latin America, various authors suggest that the quality of democratic institutions affected enfranchisement processes, including extending suffrage rights to migrants (e.g., Escobar, 2015; Finn, 2020). The same holds true in Middle Eastern and North African countries as well as Sub-Saharan Africa (e.g., Lafleur, 2015; Wellman, 2020). Overall, holding multiparty elections is a strong determinant for enacting and implementing emigrant enfranchisement in the Global South (Escobar, 2015; Palop-García and Pedroza, 2019; Wellman, 2020).

Moreover, comparative political and international relations' studies have examined the democratic norms' hypothesis since the seminal work of Huntington (1991) on the third wave of democratization. International and regional norms' diffusion occurs when states replicate other governments' decisionmaking (Elkins and Simmons, 2005). This hypothesis is likely to spread across borders, such as through waves of emulation and diffusion (Turcu and Urbatsch, 2015). Neighboring countries are the main responsible actors in emulating such norms, given their fairly high and mutual information flows (Kopstein and Reilly, 2000). When country A has experimented with innovative policies that function well, neighboring country B may actively promulgate similar policies to resolve domestic challenges (Cortell and Davis, 1996; Gleditsch and Ward, 2006). States must have a 'good' or 'positive' perception of the countries they mimic, particularly when the policies have not been conclusively proven before. As such, this hypothesis works as a social process within adjacent geographic locations over time (Brinks and Coppedge, 2006; Turcu and Urbatsch, 2015).

Alongside this neighboring diffusion effect, scholars have also emphasized the role of nonresident nationals and noncitizen residents as agents of democratic norms diffusion (PérezArmendariz and Crow, 2010; Turcu and Urbatsch, 2015). Experiences of Latin American emigrants in the United States, for instance, suggest that enactment and implementation occurred from origin countries not only due to encouragement of their political elite, but also bottom-up demand for dual citizenship and external voting rights (Jones-Correa, 1998; Lafleur, 2013). As such, emigrants themselves became agents of democratization (Escobar, 2017).

Likewise, extending external voting rights to nonresident populations also lies within existing literature on electoral preferences, particularly the burgeoning literature on the voting alignment of citizens residing abroad (e.g., Verdery, 1998; Turcu and Urbatsch, 2020a). A growing number of contributions have explained the increasing interest of ruling parties and coalitions in enfranchising nonresident citizens-again, similar to their interest in other excluded minority groups throughout history-given their strategic calculations (e.g., Østergaard-Nielsen et al., 2019; Umpierrez de Reguero and Dandoy, 2020; Wellman, 2020). This logic 
relies largely on two theoretical arguments: 1) electoral reform will only occur if ruling parties or a coalition is willing to incorporate new actors into the political game (Boix, 1999) or 2 ) as a coercion tactic in which incumbent parties or coalitions seek to deter potential challengers from opposition parties (Geddes, 2005; Magaloni, 2006; Simpser, 2013). While the first argument most likely relates to a democratic context, the second is inherently associated with the de facto hegemonic nature of party systems (Wellman, 2020). By assuming that incumbent parties or coalitions will grant suffrage rights to nonresident citizens, these arguments lead homeland politicians to pursue a new niche of potential voters to support them.

So, which political parties support external voting rights and why? In Latin America, emigrants' political rights were mostly promoted by right-leaning parties, under the influence of 'strongmen' in power prior to the 1990s (Escobar, 2015). Yet, the ascension of outsiders into politics-e.g., Hugo Chávez (Venezuela), Rafael Correa (Ecuador), and Evo Morales (Bolivia), as well as being associated with an inclusionary radical populism - has been accompanied by the adoption and implementation of external voting provisions that lean toward left-wing actors (Bermúdez et al., 2017; Erlingsson and Tuman, 2017; Umpierrez de Reguero et al., 2020). In Sub-Saharan Africa, the opposition parties, probably driven by a rational-choice estimation, often support emigrant enfranchisement given the aversion that incumbent parties can generate from the diaspora related to "domestic discontent, lack of opportunities, and conflicts" (Wellman, 2020, p. 3). In Europe, external voting rights are often correlated with mainstream right-wing parties (Østergaard-Nielsen et al., 2019). For example, in Italy, the National Alliance is associated with the evolution of emigrant enfranchisement and paying attention to emigrants' wellbeing (Lafleur, 2013). In France and Spain, citizenship reforms, in particular the rights of nonresident citizens, have been endorsed by mainstream right-leaning parties (Joppke, 2003).

Beyond the left-right axis of party politics, it seems that nonresident citizens are more prone to vote for green parties as compared to domestic voters (Turcu and Urbatsch, 2020b). Overall, many homeland parties are highly interested in campaigning across borders (Paarlberg, 2017; ØstergaardNielsen and Ciornei, 2019; Burgess, 2020; Jakobson et al., 2020; Kernalegenn and Van Haute, 2020; Rashkova, 2020; Camatarri, 2021; Umpierrez de Reguero and Dandoy, 2021). As effective political competition is a substantial aspect for detecting a mutually exclusive classification between democracy and authoritarianism, we pose a fruitful debate of party politics in Small-N: Unpacking the Political RegimeEmigrant Enfranchisement Relation to answer how and why some political regimes present counterintuitive results on emigrant enfranchisement.

\section{LARGE-N ANALYSIS: IS DEMOCRACY CONDUCTIVE TO EMIGRANT ENFRANCHISEMENT?}

In order to answer if democracies or autocracies are more likely to enfranchise nonresident citizens, we constructed a cross-national dataset, which includes information for 158 countries from 1896 to $2019(\mathrm{~N}=16,289)$. In other words, our unit of analysis is country year. In our dataset, Norway was the first country to enact external voting rights for some civilians (i.e., not only for diplomatic and military personnel) in 1896 (Saby, 1918), so we take this year as the starting point in our assessment. If a country was established later than this time, we adhere observations to our dataset the same year they obtained formal recognition as a sovereign territory, as recognized by most states and international organizations. For instance, we incorporated Bosnia-Herzegovina and Slovakia in 1992 and 1993, respectively. Given the complex search for accurate emigrant electoral rights in some contexts (e.g., authoritarian regimes and when the documents verifying the emigrant enfranchisement stages are not publicly available), our sample numbers 158 origin countries (see Supplementary Table S1).

Our dataset relies on primary and secondary sources. We corroborated each observation on the enactment and first application of emigrant enfranchisement from online archives and existing official documents from electoral commissions and ministries of interior about electoral processes abroad. We also gathered dataset observations by consulting reputable indexes such as the Regimes of the World (RoW), the measure from the Varieties of Democracy (V-DEM, Coppedge et al., 2020) project, and the Electoral Laws Indicators (ELECLAW) from the Global Citizenship Observatory (GLOBALCIT, Schmidt et al., 2019). In addition, we consulted supplementary data in academic references (e.g., Escobar, 2017; Østergaard-Nielsen et al., 2019; Wellman, 2020) to enrich our dataset.

\section{Measures}

Similar to recent relevant contributions (e.g., Lafleur, 2013; Palop-García and Pedroza, 2019; Wellman, 2020), we operationalized emigrant enfranchisement as a two-stage process. The first involves enacting external voting rights, or de jure emigrant enfranchisement. This can be verified, for example, in an electoral code, constitution, executive/royal decree, or other official legal documents. Although the second stage could be considered regulation of the law to organize electoral voting rights (such as in Palop-García and Pedroza, 2019), we opted for a more parsimonious operationalization comprising implementation, or de facto emigrant enfranchisement, which is the first time that the nonresident population votes in home-country elections. As such, we can distinguish the countries that have failed to implement emigrant enfranchisement despite having promulgated it in their legal framework; the distinction also caters to further analyses considering nonresident citizens' voter turnout and policy reversals (e.g., Brand, 2006; Wellman, 2020). De jure and de facto emigrant enfranchisement serve as our dependent variables.

Despite the variety of methods in which external voting rights can be enacted and implemented (e.g., Lafleur, 2013; Collyer, 2014a; Hutcheson and Arrighi, 2015; Schmid et al., 2019), our conceptualization excludes a restrictive eligibility. For instance, if a country only allows certain categories of citizens belonging to the demos (e.g., diplomatic and military personnel) or if nonresident citizens are required to travel during election day 


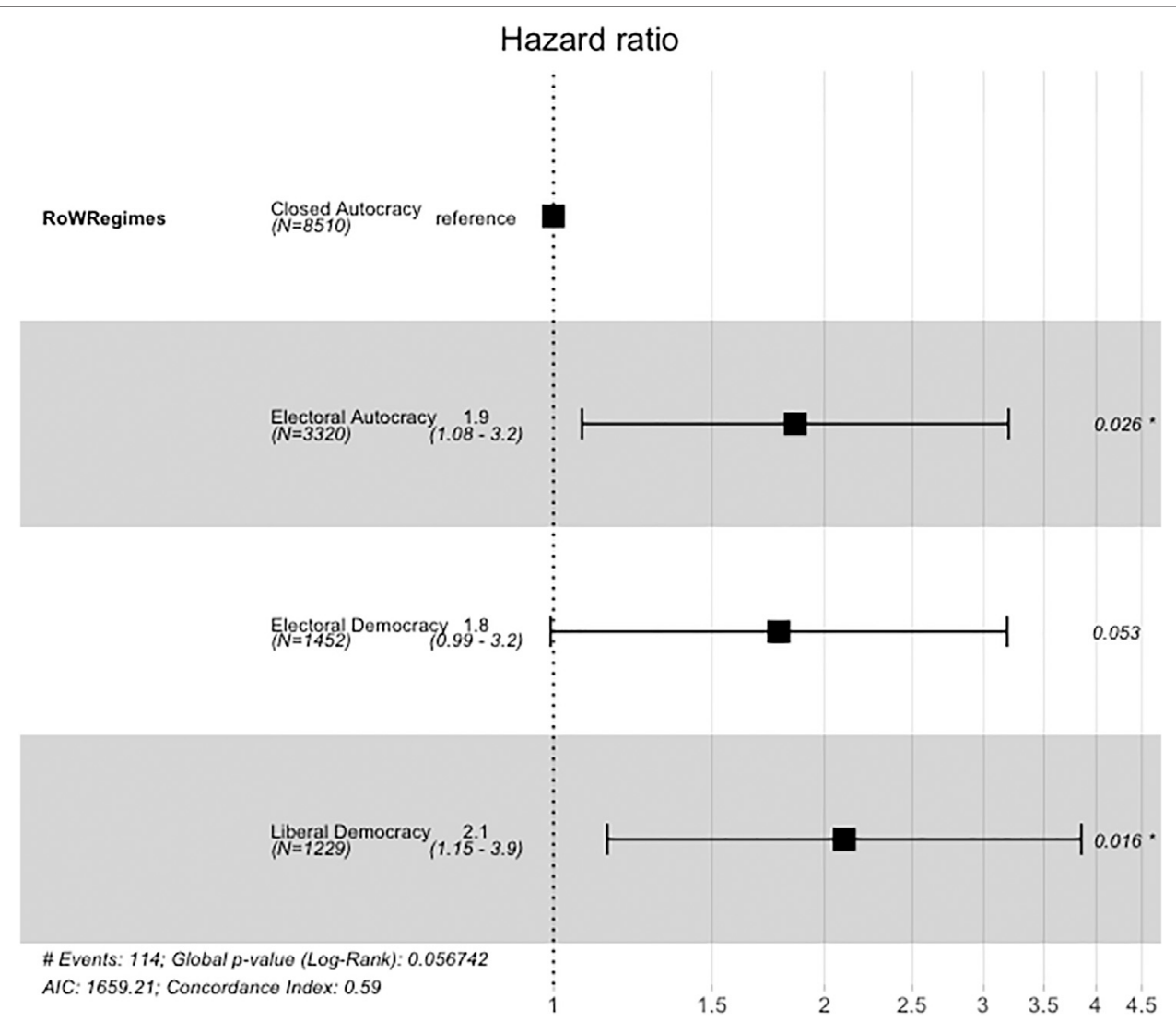

FIGURE 2 | Hazard ratios, de jure emigrant enfranchisement vs. political regimes.

to their origin country to participate in homeland elections, either independently or sponsored by political elites, we code it as " 0 " for absence of emigrant enfranchisement.

Following Lührmann and colleagues' (2018) classification, we operationalized political regimes as a four-value ordinal independent variable, coding "closed autocracy" as "0," "electoral autocracy" as "1," "electoral democracy" as " 2 ," and "liberal democracy" as "3." Accordingly, we identify in which type of political regime emigrant enfranchisement is most likely to be present or had emerged. We also include two V-Dem indexes (Liberal Democracy and Electoral Democracy) for robustness checks.

We control our models by incorporating two dummy variables: whether the country belongs to the European Union (EU) or the Organisation of Economic Cooperation and Development (OECD). Following Rhodes and Harutyunyan (2010), we use economic development as controls. Alongside the fact that most democracies around the globe pertain to those institutional clusters (therefore, we expect that being a member of either organization positively correlates to external voting rights), we add the variables EU and OECD because de facto emigrant enfranchisement in particular requires considerable fiscal and bureaucratic resources, which are more copious with higher levels of development.

\section{Estimation Strategy}

As other studies related to migrant voting rights (e.g., Turcu and Urbatsch, 2015; Kayran and Erdilmen, 2020), we use proportional survival models to estimate the relation between political regime and the timing of emigrant enfranchisement. Proportional survival analyses are also well known as event history statistical models. We selected the Cox Proportional Hazard Model as the core method over a binary or ordinal logistic regression in our analysis, given the flexibility of measuring a set of events over time. We also incorporate a set of ordinal logistic regressions, adding controls to isolate the temporal factor, as robustness checks (see Supplementary Table S2). Employing a Cox Proportional Hazard model, we are interested in examining the extent to which democracy predicts the timing of the adoption and implementation of emigrant enfranchisement. The main goal of this method is to generate hazard ratios $h(t)$ $x$ ) that represent the risk of shifting from one country to another, which for our purpose means shifting from the absence of emigrant enfranchisement (i.e., "0") to enactment (de jure enfranchisement "1") and/or first application (de facto enfranchisement " 1 ") of external voting rights, due to their absence up to time $t$. We calculate the covariates $x$ on whether they predict the timing of emigrant enfranchisement within our sample of 158 countries. 


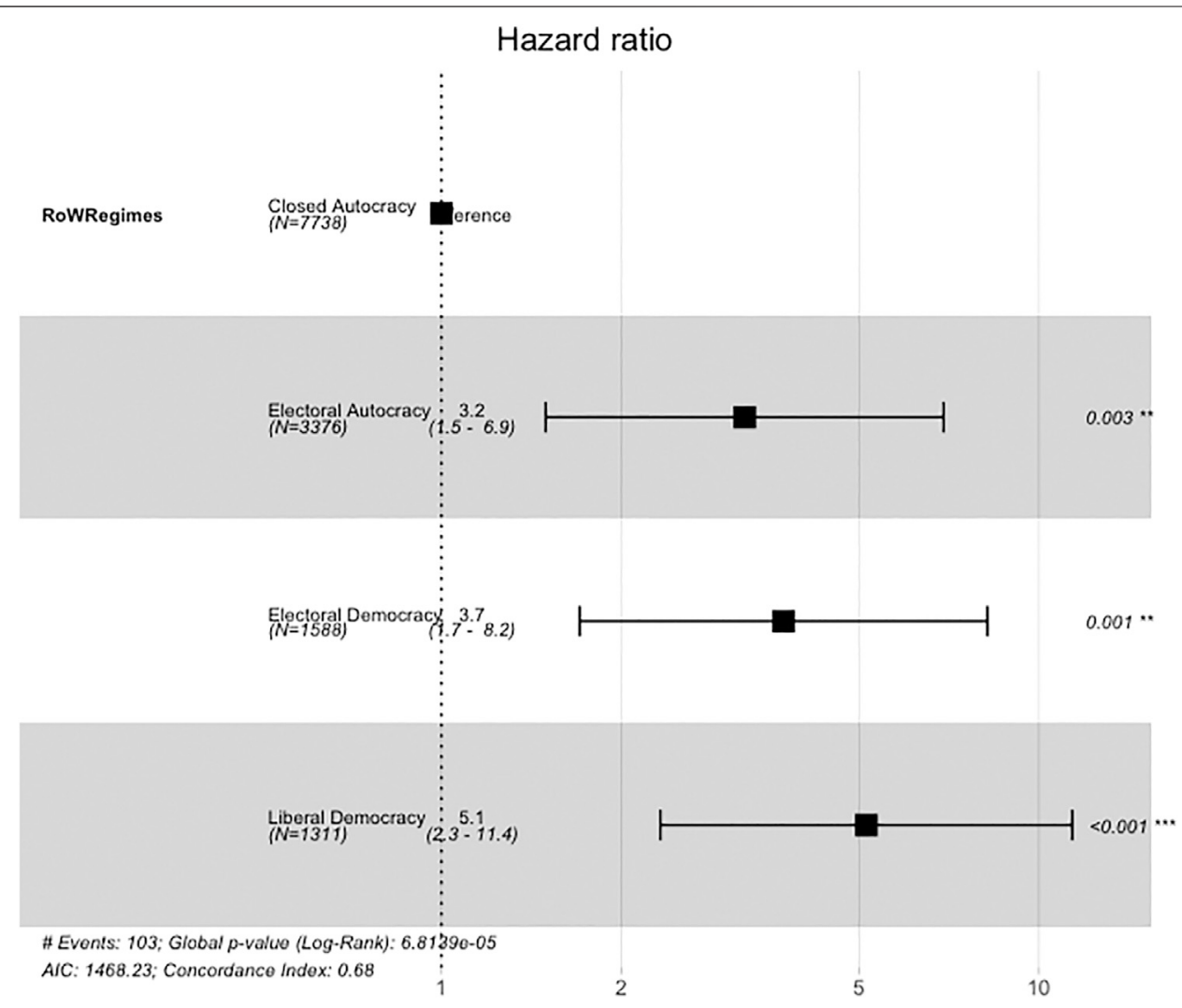

FIGURE 3 | Hazard ratios, de facto emigrant enfranchisement vs. political regimes.

\section{Findings}

Our models are significant (global $p$-value $[\log$-Rank] $<0,10$ ) and the Concordance indexes oscillate from 0.59 to 0.68 , which are the habitual results when Cox Proportional Hazard Ratios satisfactorily fit. Additionally, each model passed the linktest diagnostic for misspecification.

Figure 2 shows that de jure emigrant enfranchisement positively correlates to democracy. As expected, higher levels of inclusion and contestation, along with higher indicators in terms of rule of law and liberal principles, result in higher odds of enacting external voting rights. We find liberal democracies are around two times more likely to enact voting rights for nonresident citizens (HR 2.1; $p$-value $<0.05$ ), as compared to closed autocracies. While electoral democracy is insignificant in the model, electoral autocracies are also positively correlated with de jure emigrant enfranchisement, more than twice as likely as compared to closed autocracies (HR 1.9; $p$-value $<0.05$ ). This is unsurprising since most closed autocracies such as North Korea and Saudi Arabia do not hold elections. A few exceptions appear, such as Algeria under the command of Houari Boumédiène (1965-1978), which passed a modest external voting rights provision in the 1976 Constitution (Brand, 2010).

Figure 3 complements our previous results by showing the timing of de facto emigrant enfranchisement. In this occasion, all types of political regimes are significant. Similar to our first model in which democracy was conducive to de jure emigrant

TABLE 1 | Hazard ratios, emigrant enfranchisement vs. political regimes.

\begin{tabular}{|c|c|c|c|c|}
\hline & \multicolumn{2}{|c|}{ De jure emigrant enfranchisement } & \multicolumn{2}{|c|}{ De facto emigrant enfranchisement } \\
\hline & M1 & M2 & M3 & M4 \\
\hline Liberal democracy (Index V-DEM) & $0.85^{\star \star \star}$ & & $0.83^{\star \star \star}$ & \\
\hline EU & & 1.01 & & 1.02 \\
\hline OECD & 1.03 & & 1.03 & \\
\hline Concordance index & $0.73(\mathrm{se}=0.02)$ & $0.77(\mathrm{se}=0.02)$ & $0.78(\mathrm{se}=0.02)$ & $0.81(\mathrm{se}=0.01)$ \\
\hline
\end{tabular}


TABLE 2 | Case selection.

\begin{tabular}{lccc}
\hline & $(\mathbf{X})$ Democracy & $\begin{array}{c}\left(\mathbf{Y}_{\mathbf{1}}\right) \text { De jure } \\
\text { emigrant enfranchisement }\end{array}$ & $\begin{array}{c}\left(\mathbf{Y}_{\mathbf{2}}\right) \text { De facto } \\
\text { emigrant enfranchisement }\end{array}$ \\
\hline Ireland & Yes & No & No \\
Uruguay & Yes & No & No \\
Turkey & No & Yes & Yes \\
Venezuela & No & Yes & Yes \\
\hline
\end{tabular}

enfranchisement, Figure 3 shows that liberal democracies are about five times more likely to implement an external voting provision (HR 5.1; $p$-value $<0.001$ ) and around four times more likely if the country is classified as an electoral democracy (HR 3.7; $p$-value $<0.001)$. Although probabilities are reduced if the country is an electoral autocracy (HR 3.2; $p$-value $<0.01$ ), it still represents a robust positive correlation to de facto emigrant enfranchisement. As in Model 1, closed autocracy is the reference category. Overall, most countries classified as autocracies display a negative outcome or ' 0 ', when referring to implementing external voting rights, regardless of whether they had previously passed a provision to enfranchise their nonresident citizens. Certain countries, such as Angola and Nicaragua, promulgated provisions to organize external voting decades ago, but have not implemented corresponding legislation (Ellis et al., 2007; Palop-García and Pedroza, 2019).

Four Cox Proportional Hazard Models ensured our results remain the same when including another measurement of democracy. Table 1 demonstrates that the probabilities of positive correlation between democracy and emigrant enfranchisement remain high. Adding two dummy variables as controls, we corroborate that a democratic regime is a strong predictor of both enacting and implementing external voting rights. Surprisingly, belonging to both the EU and OECD does not have a significant impact on the odds for origin states to undertake de jure and de facto emigrant enfranchisement. So, how and why do some democracies choose not to pass and/or implement external voting rights, while some autocracies do?

\section{SMALL-N: UNPACKING THE POLITICAL REGIME-EMIGRANT ENFRANCHISEMENT RELATION}

In this section, we aim to shed light on how different mesolevel mechanisms and state-led motivations help explain why some political regimes are deviant cases for the above-indicated results. We dive into the strategic role of political elites that lie behind country-case outliers. We use most-different cases since "most different cases that are broadly representative of the population will provide the strongest basis for generalization" (Seawright and Gerring, 2008, p. 298). On one side, we briefly analyze the current debates on emigrant enfranchisement of Ireland and Uruguay (both democracies) and specifically why they fail to enact and/or implement a provision for granting suffrage rights to nonresident citizens. On the other side, we examine de jure and de facto emigrant enfranchisement in Turkey and Venezuela, two electoral autocracies.
Although closed autocracies can also enact and/or implement external voting rights, we focus on electoral autocracies due to their higher probability to do so (see Findings; Supplementary Table S3). Emigrant enfranchisement has already been intensively explored in closed autocracies, such as in Algeria and Morocco (see Brand, 2010).

Being outliers of the nexus between political regime and external voting rights, Ireland, Uruguay, Turkey, and Venezuela provide us diversity in terms of political context, economic development, and culture. For decades, Ireland and Turkey have ranked among the top twenty of the highest migration outflows worldwide (AbadanUnat, 2011; Honohan, 2011). Currently, Venezuela is the biggest sending country in South America (Acosta et al., 2019). Meanwhile, Uruguay has a significant share of its population abroad (Margheritis, 2017; Altman, 2020). Therefore, the four country cases allow us to unpack mechanisms for their counterintuitive behavior (see Table 2) - namely, to explain their deviant outcomes.

\section{Troubles in Paradise? Democracies That Withhold External Voting Rights}

Since changing institutions in democracies is not as easy as in autocracies (Geddes, 2005), the Irish and Uruguayan cases show a set of institutional-political obstacles and setbacks for emigrant enfranchisement. Overall, both liberal democracies contain rather cautious political elites with regard to extending nonresident citizens' electoral rights, and there has been more than a single attempt to invite resident nationals to decide this issue via mechanisms of direct democracy. While Irish authorities have delayed the referendum twice on citizens living outside the state to vote in presidential elections, Uruguayans residing within the country denied voting rights to nonresident citizens in the 2009 Referendum. Over the last decade, both countries introduced law proposals in their respective parliaments. Whereas Irish authorities are still waiting for the final approval of public opinion, as of the end of 2020 , the most recent attempt for nonresident Uruguayan to vote in homeland elections was declared unconstitutional by the Supreme Court of Justice.

Beyond delays and mechanisms that promote external voting rights, it seems that de jure emigrant enfranchisement in Ireland and Uruguay must also manage to find a fitting solution to satisfy a wide majority of political sectors and public opinion. Indeed, political elites in both democracies are exceptionally concerned about certain circumstances, such as the diaspora size, as well as the political background of the country directly associated with migration outflows. 
In Ireland, parliamentary debates have arisen starting in 1991 when the Labor Party Bill posed a tentative pathway to enable Irish citizens living abroad for less than 15 years to partake in homeland elections. In the same decade, a proposal with the endorsement of the then President, Mary Robinson, suggested three senatorial seats for nonresident Irish's direct representation (Honohan, 2011). In 2002, the All-Party Committee claimed that the right to vote in elections for the lower chamber (Dáil Éireann) should remain restricted to nationals residing within the state, while recommending that the office of the Prime Minister should designate senators 'with an awareness of emigrant issues' (Government of Ireland, 2002: 59). In 2009, another proposal was outlined, this time to consider the viability of presidential elections for nonresident Irish (Honohan, 2011). A decade later, for the 2016 general election, political parties such as Fianna Fáil and Fine Gael showed a favorable perspective toward a referendum for granting external voting rights, both in their party manifestos and public speeches. In 2019, two instances of holding a referendum were halted by external events such as Brexit. Regardless, another bill endorsed by the cabinet was introduced in the lower chamber to extend the voting franchise to nonresident citizens for the presidential election on September 16, 2019.

Despite the Constitution (Art. 2) proclaiming that "the Irish nation cherishes its special affinity with people of Irish ancestry living abroad who share its cultural identity and heritage", the same normativity limited political membership to citizenship as nationality. Thus, the current bill has only included the first generation, who are passport holders, with the prospect of return. Thereby, it automatically excluded about 70 million people worldwide who self-identify as Irish. Irish authorities have discussed the exclusion, alongside having a direct district, as a way of lowering the probability of swinging elections due to the high expected electoral weight of nonresident citizens (Honohan, 2011).

In the second case of liberal democracy withholding external voting rights, proposals to grant such rights to nonresident Uruguayans were debated in Parliament and the public sphere several times (Margheritis, 2017). In 2007, a law project to bestow this franchise was voted in the parliament, led by the then ruling coalition Broad Front (Frente Amplio). Similar to Ireland, the verdict was subject to a national referendum and public opinion blocked the political initiative in 2009 (around 37\% of resident nationals voted in favor of external voting rights, which was below the electoral threshold required to amend the Constitution). Prior to the 2014 presidential elections, Uruguayan authorities made another attempt to incorporate nonresident citizens in the demos. Yet, after a long inter-institutional exchange between the Migration National Junta, which is a public institution in charge of migration issues, and the presidential office, the project failed.

A new proposal was outlined in 2015 but laid dormant in the Uruguayan Parliament (Margheritis, 2017). Owing to the leadership of the Broad Front, in 2018, Law 19.654 passed, which provided a route for the estimated $10.7 \%$ of Uruguayans who reside abroad to vote in homeland elections (Altman, 2020); it also created an electoral commission to lead regulation in the near future (Carreño, 2020). However, this legal resource was rapidly impugned by the Colorado Party, Independent Party, National Party, and People's Party. In
2020, the Supreme Court of Justice declared that Law 19.654 was unconstitutional by a unanimous decision (Carreño, 2020). As of the end of 2020, Uruguay was one of only two countries in South America, along with Suriname, that has failed to provide de jure emigrant enfranchisement.

In sum, the democracies under analysis, Ireland and Uruguay, demonstrate two constraints for extending de jure or de facto emigrant enfranchisement: the diaspora size matters, as do political elite who are hesitant about unknown nonresident citizens' political preferences. Indeed, political parties and resident citizens might feel no need to modify their status quo and grant nonresident citizen voting.

\section{Emigrant Enfranchisement in Electoral Autocracies}

Considering that changing institutions in autocracies depends on the willingness of the ultimate decision unit (Geddes, 2005), we study the Turkish and Venezuelan cases to illustrate the other side of the coin: the presence of emigrant enfranchisement in electoral autocracies, when voting from abroad is enacted and regularly applied. We introduce two mechanisms. In Turkey, external voting rights depict political elite engaged with the diaspora. In Venezuela, however, the two are separate yet not politically divorced, due to the high costs involved in repealing them.

\section{Generous External Voting Rights in Turkey: When the Incumbent Is Favored}

The Turkish 1980 military coup, and the resulting 1982 Constitution, witnessed the first steps of recognizing eligible nonresident Turkish citizens as a new electoral niche that could democratically be perceived as a method of inclusiveness. The 1980s also established a legal restriction on parties' representation by introducing a nationwide threshold of $10 \%$, which, to this day, stands as the most significant constraint to Turkey's effective multiparty system. Since the 1987 elections, eligible nonresident citizens have been able to cast ballots at Turkish border crossings for legislative elections. Yet the border-crossing ballots for the 1987 election and the following seven elections ${ }^{1}$ proved that the overseas votes did not affect the electoral results. ${ }^{2}$ As such, recognizing nonresident citizens as voters was symbolic, in part to encourage remittance inflows rather than a step toward a more inclusive democracy (Icduygu et al., 2001).

From the over two-decade experience of border crossing voting, external voters' political orientation has traditionally tended to support conservative right-wing parties over center-right or leftwing parties [Supreme Electoral Council of Turkey YSK, (2020)]. Beyond the authoritarian legacy prominent across decades in Turkey, it is worthwhile to stress that the economically motivated lower educated groups, in the 1960s and 1970s from rural Anatolian

\footnotetext{
${ }^{1}$ The elections in which eligible nonresident citizens could only vote at border crossings were the 1987, 1991, 1995, 1999, 2002, 2007, and 2011 legislative elections.

${ }^{2}$ The 2007 legislative election is an exception. An independent candidate of the proKurdish bloc candidate lost the election once the votes cast by expats came from the border crossings and were allocated to the Hakkari district by falling behind the AKP candidate.
} 
TABLE 3 | Electoral inclusiveness of nonresident Turkish voters (2014-2018).

Type of election

Presidential (first run)

Presidential (run-off)

Legislative

Referenda

Mono level (only at the national level)

Level of election

Voting eligibility lus sanguinis (Turkish and their descendants can vote from abroad) Territorial eligibility ${ }^{a}$

Residency ${ }^{\mathrm{b}}$

Source: YSK (2020).

${ }^{a}$ According to the Election Law, to set up a polling station in a country requires at least 500 registered citizens. Countries that have fewer than 500 registered Turkish nationals in their electoral rolls are exempt from enforcement (see Turkish Constitution Act no. 4320 and Act no. 1570).

${ }^{b}$ To be eligible for voting at an extraterritorial polling station, nonresident citizens have to reside abroad for six month or longer and are required to be registered at their country of residence (see Turkish Constitution Article no. 94).

TABLE 4 | Easiness to vote in Turkey (2014-2018).

\begin{tabular}{|c|c|c|c|c|c|c|}
\hline & 2014 Presidential & $\begin{array}{l}2015 \text { (June) } \\
\text { Legislative }\end{array}$ & $\begin{array}{l}2015 \text { (November) } \\
\text { Legislative }\end{array}$ & $\begin{array}{c}2017 \\
\text { Referendum }\end{array}$ & $\begin{array}{c}2018 \\
\text { Legislative }\end{array}$ & $\begin{array}{l}2018 \text { Run-off } \\
\text { presidential }\end{array}$ \\
\hline $\begin{array}{l}\text { Identification documents } \\
\text { to vote }\end{array}$ & Valid Turkish ID or Turkish passport & & & & & \\
\hline $\begin{array}{l}\text { Length of voting at the } \\
\text { overseas polling stations } \\
\text { (\# days) }\end{array}$ & $1-4$ & $1-24$ & $1-18$ & $1-14$ & $1-13$ & $1-5$ \\
\hline $\begin{array}{l}\text { Precondition for voting } \\
\text { (if eligible) }\end{array}$ & $\begin{array}{l}\text { Once by post or in-person registration at a } \\
\text { diplomatic mission, and making an } \\
\text { appointment within the polling schedule }\end{array}$ & \multicolumn{5}{|c|}{ Once by post or in-person registration at a diplomatic mission } \\
\hline $\begin{array}{l}\text { \# Of countries/polling } \\
\text { stations }\end{array}$ & $54 / 103$ & $54 / 112$ & $54 / 113$ & $57 / N A$ & $60 / 123$ & $60 / 123$ \\
\hline Voting method & In-person (at a designated polling station) & & & & \multicolumn{2}{|c|}{$\begin{array}{l}\text { In-person (at any extraterritorial } \\
\text { polling station) }\end{array}$} \\
\hline
\end{tabular}

Source: YSK (2020).

${ }^{a}$ The YSK holds discretionary rights to determine the polling length.

heartlands, started emigrating to Europe through guest worker agreements. Having overall low levels of education and without professional backgrounds, they first emigrated to Germany and subsequently to France, the Netherlands, Austria, Belgium, and Sweden (Avc1 and Kirisci, 2006). These factors contributed to the conservative orientation of their vote and, given further flows through networks of cultures of migration, such political alignment continued to grow (Sirkeci et al., 2012). This is not surprising to the burgeoning literature of migrant and nonmigrant voting alignment (e.g., Turcu and Urbatsch, 2020a; Wellman, 2020).

From the 1970s onwards, Turkish labor emigration to Western European countries declined due to the oil crisis and the European countries' saturation. The political turmoil of 1980s and 1990s in Turkey created political refugees that became the main source of the emigration wave (Fassmann and Munz, 1992; Østergaard-Nielsen, 2003; Sirkeci, 2005). These newer emigre groups from Turkey did not outnumber the economically motivated migrants, making the average sociopolitical demography of the diaspora largely conservative, despite increased voice of the opposition groups who were consisting of leftists, mostly ethnic minority Kurds and not officially recognized religious minority Alevis in guest worker residence countries (Østergaard-Nielsen, 2003; Sirkeci, 2005; YenerRoderburg, 2020).
Since the second election that the Justice and Development Party (Adalet ve Kalkınma Partisi, AKP) won in 2007, the party emerged as the successor of the banned conservative parties Welfare Party (Refah Partisi) and Virtue Party (Fazilet Partisi). Unsurprisingly, nonresident voters have shown greater support for AKP than resident voters in the guest worker resident countries, whereas in destinations where the migration is dominated by political ethnic and religious insecurities, such as in the United Kingdom and Sweden, political balance has been tilted toward pro-minority party Peoples' Democratic Party (Halklarin Demokratik Partisi, HDP) (YSK, 2020). Therefore, despite legislation that enabled enfranchising voters abroad pass and was supported by both the ruling party, the AKP, and opposition parties (Minutes of the Grand National Assembly of Turkey, 2008; Official Gazette of Turkey 26824, 2008a), the chronological significance of enabling external voting rights under the AKP's rule from the 2014 Presidential Elections onwards can hardly be seen as a coincidence (Turcu and Urbatsch, 2020a). Regardless, the grounds for enabling emigrant enfranchisement cannot be solely attributed to nonresident support for the incumbent party. Taking the counterfactual, perhaps the AKP would have played such a major role in passing the law, if the party had not received the largest share from the border crossings' ballot boxes (see the Venezuelan case below). 
TABLE 5 | Party fragmentation in Turkey.

\begin{tabular}{|c|c|c|c|c|c|c|}
\hline & \multicolumn{6}{|c|}{ Abroad } \\
\hline & ENPC/ENPP & Fragmentation & Concentration & First preference & Second preference & Turnout $^{\mathrm{a}}$ \\
\hline Presidential 2014 & 2.14 & 0.53 & 89.50 & Recep tayip erdoğan (AKP) & Ekmeleddin mehmet İhsanoğlu (CHP) & $8.37 \%$ \\
\hline Parliamentary $2015 a$ & 3.00 & 0.67 & 71.80 & AKP & HDP & $32.03 \%$ \\
\hline Parliamentary 2015b & 2.61 & 0.62 & 75.55 & AKP & HDP & $40.03 \%$ \\
\hline Presidential 2018 & 2.29 & 0.56 & 84.77 & Recep tayip erdoğan (AKP) & Muharrem İnce (CHP) & $44.05 \%$ \\
\hline \multirow[t]{3}{*}{ Parliamentary 2018} & 2.97 & 0.66 & 69.48 & $\mathrm{AKP}$ & $\mathrm{CHP}$ & $49.45 \%$ \\
\hline & \multicolumn{6}{|c|}{ Inland } \\
\hline & ENPC/ENPP & Fragmentation & Concentration & First preference & Second preference & Turnout \\
\hline Presidential 2014 & 2.33 & 0.57 & 90.75 & Recep tayip erdoğan (AKP) & Ekmeleddin mehmet İhsanoğlu (CHP) & $79.39 \%$ \\
\hline Parliamentary $2015 a$ & 3.66 & 0.73 & 65.79 & AKP & $\mathrm{CHP}$ & $83.96 \%$ \\
\hline Parliamentary 2015b & 2.99 & 0.67 & 74.88 & AKP & $\mathrm{CHP}$ & $86.63 \%$ \\
\hline Presidential 2018 & 2.64 & 0.62 & 82.89 & Recep tayip erdoğan (AKP) & Muharrem İnce (CHP) & $86.51 \%$ \\
\hline Parliamentary 2018 & 3.75 & 0.73 & 65.07 & AKP & $\mathrm{CHP}$ & $86.34 \%$ \\
\hline
\end{tabular}

Source: YSK (2020).

${ }^{a}$ We divided the total overseas votes by the total valid votes of all national jurisdictions.

\begin{tabular}{|c|c|c|c|c|c|c|c|}
\hline \multirow{3}{*}{$\begin{array}{l}\text { Coalition } \\
\text { (Main) political } \\
\text { party }\end{array}$} & \multicolumn{3}{|c|}{ Gran polo democrático } & \multicolumn{3}{|c|}{ MUD (2008-2018) } & \multirow{3}{*}{$\begin{array}{c}\text { Total share } \\
\text { of overseas } \\
\text { votes }\end{array}$} \\
\hline & \multicolumn{3}{|c|}{ PSUV } & \multicolumn{3}{|c|}{ CR, NT, JP } & \\
\hline & $\%$ (abroad) & $\%$ (inland) & Difference & $\%$ (abroad) & $\%$ (inland) & Difference & \\
\hline Presidential 2000 & 25.91 & 56.97 & -31.07 & 70.32 & 35.71 & 34.61 & $0.12 \%$ \\
\hline Presidential 2006 & 24.47 & 62.96 & -38.49 & 75.37 & 36.80 & 38.58 & $0.29 \%$ \\
\hline Presidential 2012 & 8.45 & 55.33 & -46.87 & 90.54 & 44.52 & 46.02 & $0.45 \%$ \\
\hline Presidential 2013 & 7.43 & 50.79 & -43.36 & 92.48 & 48.95 & 43.53 & $0.40 \%$ \\
\hline
\end{tabular}

Source: CNE (2020).

The 2014 Presidential Elections were the first in which nonresident citizens could vote from their residence country under certain conditions (see Table 3). Despite receiving the highest support for the AKP's presidential candidate, nonresident citizens' voter turnout was lower than expected but still indicated higher support overall for the AKP (Abadan-Unat et al., 2014). Therefore, the AKP rapidly addressed the main obstacles ${ }^{3}$ that previously appeared to be related to the implementation process.

The changes to implementation, imposed to facilitate external voting ${ }^{4}$ with each election held after 2014, translated into higher voter turnout, evident from consecutive election results (see Table 4). ${ }^{5}$ However, the difficulties of getting to the polling

\footnotetext{
${ }^{3}$ Including electoral roll registration requirement, appointment requirement to vote at a designated polling station at a country of residence, the geographical proximity of the polling stations to the voters' residents.

${ }^{4}$ Such as withdrawing the appointment system, extending the voting period, increasing the number of polling stations, and permitting eligible expats to vote at any extraterritorial polling station in addition to border crossings.

${ }^{5}$ There are no certain data on the number of people with a Turkish background; yet according to the Turkish Ministry of Foreign Affairs around six million Turkish people are living overseas, and according to the last elections that were held in 2018 over three million are qualified to vote for the Turkish legislative and presidential elections and referenda.
}

station did not have an inclusive solution in practice. Despite the 2008 amendment to make postal voting possible, in-person voting has remained the only method of casting a ballot (Official Gazette of Turkey 26927, 2008b, July 05, 2008). In parallel, the AKP promoted voting by introducing a highly active and systematic mobilization engagement with the AKP's sympathizers, via the AKP's overseas satellites and pro-AKP diaspora rallies held in major European cities (Burgess, 2020; Yener-Roderburg, 2020).

As indicated, the AKP has benefited greatly from nonresident voters, particularly labor migrants. This included launching its overseas mobilization efforts as part of its new diaspora policy, as soon as it acquired the power as ruling party in 2002 via the party's overseas satellites, such as the lobbying institution International Democrats (Uluslararası Demokratlar Birliği, UID), state institutions including the Turkish missions abroad, the Office for the Turks Abroad and Related Communities (Yurtdışı Türkler ve Akraba Topluluklar Başkanlığ , YTB), and other organizations including the Turkish-Islamic Union for Religious Affairs (Diyanet İşleri Türk İslam Birliği, DITIB) (Adamson, 2018; Sahin Mencutek and Baser, 2018; Yanasmayan and Kaşl1, 2019; Arkilic, 2020). The activities of these organizations included but were not limited to reaching out to the addresses of the electorates, canvassing and registering the DITIB members to the electoral role, and most 
TABLE 7 | Easiness to vote in Venezuela (1999-2018).

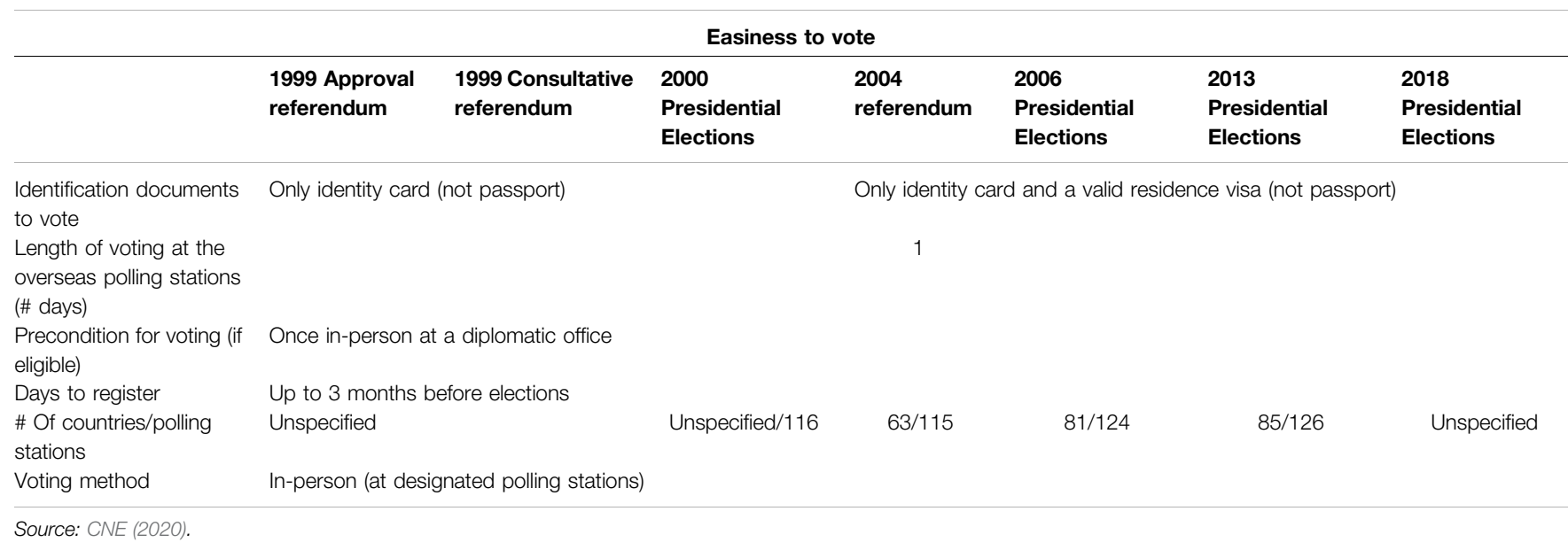

significantly providing free regular shuttle bus services to vote (Yener-Roderburg 2020).

The shuttle bus service transported party supporters from short- and long-distance locations to polling stations and provided supplementary food, which largely eliminated the inperson voting hardships for AKP sympathizers. While the inperson voting method might equate to a negative determinant factor for some Turkish voters abroad, one AKP supporters among our respondents (Supplementary Table S4) did not indicate any discomfort with it. He asserted: "I am not bothered that I needed to travel $200 \mathrm{~km}$ [Konstanz to Karlsruhe, Germany] to vote; my party has picked me up from my home door and dropped me back off. I have not spent even a cent" (TR1), whereas another respondent who openly supported the main opposition party, the Republican People's Party (Cumhuriyet Halk Partisi, CHP), remarked, "I called the shuttle bus service of the AKP and because I could not give a reference name that would show that I am an AKP supporter, they did not sign me up for the shuttle list" (TR2). Other competing party supporters tried to offer other transportation services, but the efforts of the party supporters remained scarce and lacked centralization. The extensive mobilization efforts in providing shuttle buses stand out as one of the critical reasons why the AKP's vote share has increased more in every succeeding election, as compared to competing parties (see Table 5).

Although party fragmentation increased in Turkey over time, abroad the reality approximates to a bipartisan system (see Table 5). Furthermore, the share of overseas votes over the inland votes has increased each election. Given the imbalanced vote share of the parties, particularly of the AKP and Peoples' Democratic Party (Halkların Demokratik Partisi, HDP) within the country and abroad, this scenario has changed the overall electoral balance. In the June 2015 and 2018 elections, respectively two and then one legislative seats shifted to the AKP, whereas only one seat changed to the HDP in the former election and the following elections did not swing votes in HDP's favor. As the diaspora favors the AKP, this country case shows us one mechanism why external voting rights are implemented: as a strategy to benefit the incumbent.

\section{Restricting Emigrant Enfranchisement in Venezuela: When the Incumbent is Challenged}

In Venezuela, de jure emigrant enfranchisement was adopted in 1993, under the right-wing government led by the former President Rafael Caldera (founder of the National Convergence Party). To a large extent, enactment occurred as a result of pressure from nonresident Venezuelans (Escobar, 2015). Yet, political elites demonstrated their unwillingness to regulate and apply external voting rights until 1998-1999 in the first presidential term of Hugo Chávez, recurrently classified as an inclusionary radical populist (e.g., by Mudde and Rovira Kaltwasser, 2013). In 1999, less than 4,000 nonresident Venezuelans participated in two referenda: one to support or reject the necessity of a new constitution and another to approve a constitutional draft. In these elections, emigrant enfranchisement for nonresident Venezuelans was both promulgated and implemented in the Constitution of 2000 (Escobar, 2017; Umpierrez de Reguero et al., 2020).

After this constitutional reform, Chávez was reelected with more than $55 \%$ of the inland votes, yet Venezuelans living abroad were not electorally aligned (see Table 6). Chávez obtained only about $25 \%$ of the overseas votes, as Venezuelans residing abroad favored the then opposition candidate, Francisco Arias Cardenas from the Radical Cause (Causa Radical, CR). Prior to the 2006 presidential election, Chávez and his party, the United Socialist Party of Venezuela (Partido Socialista Unido de Venezuela, PSUV), introduced an amendment to the Electoral Law to restrict external voting rights' access and eligibility. This amendment provided that Venezuelans residing abroad needed a valid residence permit (visa) from their residence country in their passports. This immediately excluded dual citizens from voting in homeland elections (Bello, 2018).

While the dominance of the ruling party gradually increased within Venezuela, the electoral register of overseas voters remained almost the same over time and their votes increasingly favored the opposition (see Table 6), both in presidential elections and referenda. For instance, in 2013 
around $92.5 \%$ of nonresident Venezuelans voted for Henrique Capriles from the First Justice party (Justicia Primero, JP). Yet, there is evidence of Venezuelans residing in autocracies such as Cuba showing overwhelming support for the ruling preelectoral coalition in every election they could participate in between 1999 and 2018 (CNE, 2020). This can be easily explained by the regime commonalties shared by the Cuban and Venezuelan political environments, as well as their proactive bilateral relations.

After former president Chávez's death, the then vice-president Nicolás Maduro ascended into power until presidential elections in late 2013. Since his 'reelection' ${ }^{6}$ in 2018, external voting rights for Venezuelans have suffered various arbitrary barriers-in addition to the eligibility restrictions defined by law-namely a lack of information on voting procedures, tight deadlines for registration, a reduced number of extraterritorial polling stations (e.g., closing the diplomatic office in Miami), and diplomatic authorities' unwillingness to change electoral domicile (from Venezuela to the residence country) (Umpierrez de Reguero et al., 2020; VE1; VE2). Indeed, the 2018 Presidential Elections serves as an unambiguous example verifying the restrictive effects of de facto emigrant enfranchisement. As of the beginning of 2021, nonresident nationals number, almost six million, due to the Venezuelan exodus ( $\mathrm{R} 4 \mathrm{~V}, 2021)$, and only about 110,000 could and/or were registered to vote in the last election [Electoral National Council of Venezuela CNE, (2020)].

As Venezuelan de facto emigrant enfranchisement favored opposition groups, it has become more complex over time. According to the Electoral Law, Venezuelans abroad can only cast their vote in-person at any diplomatic office; as many have fled the country, they failed to update their legal documents (especially birth certificates and criminal background checks, which must be issued by the Venezuelan government) to establish a legal status in the residence country (Freier and Parent, 2018; Acosta et al., 2019; Umpierrez de Reguero et al., 2020).

The reform has tended to eliminate the possibility for certain emigrants to qualify as voters if they live abroad only temporarily or in transit, as it has been the case for many undocumented Venezuelans whose access may be completely denied. Restrictions stemming from registration requirements or procedures appear to be just as important as restraints on access and eligibility. When access requirements may be more inclusive to cast a vote, voting is significantly constrained by the preceding registration procedures (see Table 7).

Other (documented) Venezuelans have expressed their desire to avoid any interactions with diplomatic personnel, given their notable connection to Nicolas Maduro's government, particularly from his 'reelection' in 2018. As Buxton (2018) pinpointed, the ruling regime is heavily supported by the armed forces, as to maintain state administration composed by active and retired military. Therefore, the emigrants' dislike and mistrust toward

${ }^{6}$ Nicolás Maduro became president with the lowest rate of participation (46.02\%) in decades, with only 8.6 million people from 20 million Venezuelans able to vote (BBC Mundo, 2018). offices abroad and their diplomatic personnel are justified, as one of our respondents admitted, "we are even scared to go to the embassy and give our name and sign up and the whole thing, because we feel like all of that is controlled by the government" (VE3).

The second issue is that elections in Venezuela are not always free and fair (particularly the last one of 2018), and the field of political competition is uneven, tipped in favor of the incumbent's political coalition (Buxton, 2018; Coppedge et al., 2020). Among the reduced number of Venezuelans able to register abroad, even fewer are willing to vote because of the fraudulent and undemocratic context of Venezuelan elections.

In the 2018 Presidential Elections, the Bureau of Democratic Unity (la Mesa de la Unidad Democrática, MUD), the most important coalition of opposition political parties in the country, decided that no opposition candidate would run in those elections and started a campaign against electoral participation in response to the lack of transparency in the process. However, if one takes the results of 2013 Presidential Elections, opposition leader Capriles lost the elections by a minimum difference of 141,385 votes against incumbent Maduro-it is to say that if more Venezuelans abroad would have been registered to vote, nonresident citizens' voter turnout could have swung the electoral results.

In sum, if electoral procedures such as registration abroad and the requirement of legal residency were to change, the number of voters abroad would increase and could even play a decisive role in electoral results, most likely favoring the opposition. Nevertheless, in practice, the difficulties for registration at Venezuelan diplomatic offices have led to a tiny number of voters (reaching only about $3 \%$ of the population abroad being eligible to vote) and the low number of registered voters means less chance an opposition party could win an election.

\section{CONCLUSION}

In this article, we examined the relation between political regimes and external voting rights. Our dependent variables comprised de jure and de facto emigrant enfranchisement, while our main explanatory factor was structured from a four-value variable of political regimes: liberal and electoral democracies as well as electoral and closed autocracies. First, we ran a set of Cox Hazard Proportional models, which contributed to identifying whether democracy is a driver of emigrant enfranchisement. Second, using most-different cases, we unpacked how and why the deviant country cases of Ireland, Uruguay, Turkey, and Venezuela behave differently than expected. We delved into state-led motivations and mesolevel mechanisms that lie behind these country outliers. For the first component, we used a global longitudinal dataset, whereas for the second we conducted and analyzed interviews, official documents, and secondary sources.

Our findings report a positive correlation between democracy and external voting rights: higher levels of inclusion and party competition mean higher probabilities of adopting and implementing the voting franchise for 
nonresident citizens. The deviant liberal democracies under study, Ireland and Uruguay, demonstrated that in certain contexts with a relatively large diaspora size, and where part of the political spectrum is doubtful about nonresident citizens' political orientations, states may deem it better not to grant $d e$ jure or de facto emigrant enfranchisement. Political elites, even resident nationals, feel no need to change the status quo and thus continue withholding nonresident citizen voting. The electoral autocracies under analysis, Turkey and Venezuela, showed that once external voting rights are enacted, states considered it more ideal to calibrate the intensity and leverage of this suffrage, depending on the benefits that the incumbents could gain from nonresident citizens. When the diaspora favors (or is perceived to favor) the incumbency, then external voting rights are extended; otherwise, they are restricted or limited for nonresident citizens.

We encourage scholars interested in the relation between emigrant enfranchisement and political regimes to expand systematic comparisons over time. One case study of interest, Croatia, could hold another mechanism overlooked in this article. Croatia was an electoral autocracy when it granted emigrant enfranchisement but is now a liberal democracy, possibly offering further refinement to the window-of-opportunity hypothesis. Scholars also need to increase the dialogue between those involved in exploring authoritarianization and external voting rights and those interested in the window-of-opportunity and norms diffusion hypotheses, to explain how and why states enfranchise nonresident citizens. Moreover, we invite scholars and practitioners to replicate or refine our theoretical appraisal in other autocracies, such as Angola and Nicaragua, that enacted provisions for emigrant enfranchisement but have failed to regulate and apply them.

Looking to electoral autocracies that still implement external voting rights, disenfranchisement would be a contrasting scenario for future

\section{REFERENCES}

Abadan-Unat, N., Çidam, V., Cinar, D., Kadirbeyoglu, Z., Kaynak, S., Ozay, B., et al. (2014). Voting behaviour of euro-Turks and Turkey's presidential elections of 2014. Bonn: Friedrich Ebert Stiftung.

Abadan-Unat, N. (2011). Turks in Europe: from guest worker to transnational citizen. New York: Berghahn Books.

Acosta, D., Blouin, C., and Freier, L. F. (2019). "La emigración venezolana: respuestas latinoamericanas," in Documentos de trabajo (Madrid: Fundación Carolina), 3.

Adamson, F. B. (2018). Sending states and the making of intra-diasporic politics: Turkey and its diaspora(s). Int. Migration Rev. 53 (1), 210-236. doi:10.1177/ 0197918318767665

Allen, N., Wellman, E. I., and Nyblade, B. (2019). "Extraterritorial voting rights and restrictions dataset 1980-2017," in Paper presented at the Canadian political science association conference, Vancouver, BC, June 1-7, 2019.

Altman, D. (2020). V-Dem Working Paper No. 106. Voting rights of denizens and expats: adjusting democracy indices to the age of mass migration. Available at: https://ssrn.com/abstract $=3688030$ (Accessed September 1, 2020).

Arkilic, A. (2020). Explaining the evolution of Turkey's diaspora engagement policy: a holistic approach. Diaspora Stud. 14 (1), 1-21. doi:10.1080/09739572. 2020.1839688 research. As the regime transition from democracy to autocracy is a reality in some country cases such as Venezuela, there is an opportunity to delineate future guidelines for scholars interested in authoritarian endurance and disenfranchisement processes.

\section{DATA AVAILABILITY STATEMENT}

The original contributions presented in the study are included in the article/Supplementary Material; further inquiries can be directed to the corresponding author.

\section{ETHICS STATEMENT}

The studies involving human participants were reviewed and approved by the University of Duisburg-Essen and University Casa Grande. The patients/participants provided their written informed consent to participate in this study.

\section{AUTHOR CONTRIBUTIONS}

All authors listed have made a substantial, direct, and intellectual contribution to the work and approved it for publication. The order of the authorship, however, is a direct result of the workload undertaken by each author.

\section{SUPPLEMENTARY MATERIAL}

The Supplementary Material for this article can be found online at: https://www.frontiersin.org/articles/10.3389/fpos.2021.636734/ full\#supplementary-material.

Avc1, G., and Kirisci, K. (2006). Turkey's immigration and emigration dilemmas at the gate of the European union. Migración y Desarrollo 7 (2), 123-173. doi:10.35533/myd.0407.ga.kk

Bauböck, R. (2015). Morphing the demos into the right shape. Normative principles for enfranchising resident aliens and expatriate citizens. Democratization 22 (5), 820-839. doi:10.1080/13510347.2014.988146

BBC Mundo (2018). Elecciones en Venezuela: nicolás Maduro gana las presidenciales según el consejo nacional electoral y henri falcón cuestiona el resultado. Available at: https://www.bbc.com/mundo/noticias-america-latina44192065 (Accessed May 21, 2018).

Bello, C. (2018). ¿Por qué cerca del 3\% de los millones de venezolanos en el extranjero va a votar? Available at: Euronews Online: https://es.euronews.com/ 2018/05/17/-por-que-solo-cerca-del-3-de-los-millones-de-venezolanos-en-elextranjero-va-a-votar- (Accessed May 17, 2018).

Bermúdez, A., Lafleur, J.-M., and Escrivá, Á. (2017). Contribuyendo a la democracia en países de origen: el voto externo de los migrantes andinos. Am. Lat. Hoy. Rev. Cienc. Soc. 76 (76), 35-54. doi:10.14201/alh2017763554

Boix, C. (1999). Setting the rules of the game: the choice of electoral systems in advanced democracies. Am. Polit. Sci. Rev. 93 (3), 609-624. doi:10.2307/ 2585577

Brand, L. A. (2010). Authoritarian states and voting from abroad: North African experiences. Comp. Polit. 43 (1), 81-99. doi:10.5129/001041510x12911363510439

Brand, L. A. (2006). Citizens abroad: emigration and the state in the Middle East and North Africa. New York, NY: Cambridge University Press. 
Bratton, M., and Van de Walle, N. (1997). Democratic experiments in Africa: regime transitions in comparative perspective. New York, NY: Cambridge University Press.

Brinks, D., and Coppedge, M. (2006). Diffusion is no illusion: neighbor emulation in the third wave of democracy. Comp. Polit. Stud. 39 (4), 463-489. doi:10.1177/ 0010414005276666

Burgess, K. (2020). Courting migrants: how states make diasporas and diasporas make states. New York, NY: Oxford University Press.

Buxton, J. (2018). Venezuela: a las puertas del abismo. Revista de Ciencia Política 38 (2), 409-428. doi:10.4067/s0718-090x2018000200409

Camatarri, S. (2021). Transnational outreach efforts and electoral performance of Italian parties abroad: do they earn what they deserve? APSC 54 (1), 117-118. doi:10.1017/s1049096520001171

Carreño, L. (2020). Suprema Corte declaró inconstitucional la ley que interpretaba que los uruguayos podían votar en el exterior. El Observador. Available at: https:// www.elobservador.com.uy/nota/suprema-corte-declaro-inconstitucional-leyque-interpretaba-que-uruguayos-podian-votar-en-el-exterior-2020424173616 (Accessed April 24, 2020).

Clark, W. R., Golder, M., and Golder, S. N. (2017). Principles of comparative politics. Washington DC: CQ Press.

CNE (2020). Resultados electorales-Venezuela. Available at: http://www4.cne. gob.ve/ (Accessed December 7, 2020).

Collyer, M. (2014a). A geography of extra-territorial citizenship: explanations of external voting. Migration Stud. 2 (1), 55-72. doi:10.1093/migration/ mns008

Collyer, M. (2014b). Inside out? Directly elected 'special representation' of emigrants in national legislatures and the role of popular sovereignty. Polit. Geogr. 41, 64-73. doi:10.1016/j.polgeo.2014.01.002

Coppedge, M. (2012). Democratization and research methods. New York, NY: Cambridge University Press.

Coppedge, M., Gerring, J., Knutsen, C. H., Lindberg, S. I., Teorell, J., Altman, D., and Lührmann, A. (2020). V-Dem dataset V10. Available at: https://www.vdem.net/en/data/reference-materials-v10/ (Accessed March 10, 2020).

Cortell, A. P., and Davis, J. W. (1996). How do international institutions matter? The domestic impact of international rules and norms. Int. Stud. Q. 40 (4), 451-478. doi:10.2307/2600887

Dahl, R. A. (2008). Democracy and its critics. New Haven, CT: Yale University Press.

Dahl, R. A. (1971). Polyarchy: participation and opposition. New Haven, CT: Yale University Press.

Elkins, Z., and Simmons, B. (2005). On waves, clusters, and diffusion: a conceptual framework. Ann. Am. Acad. Polit. Soc. Sci. 598 (1), 33-51. doi:10.1177/ 0002716204272516

Ellis, A., Navarro, C., Gratschew, M., and Braun, N. (2007). Voting from abroad: the international IDEA handbook. Stockholm and Mexico: IDEA and IFE.

Erlingsson, H., and Tuman, J. P. (2017). External voting rights in Latin America and the caribbean: the influence of remittances, globalization, and partisan control. Latin Am. Pol. 8 (2), 295-312. doi:10.1111/lamp.12125

Escobar, C. (2015). Immigrant enfranchisement in Latin America: from strongmen to universal citizenship. Democratization 22 (5), 927-950. doi:10.1080/ 13510347.2014.979322

Escobar, C. (2017). Migration and franchise expansion in Latin America. San Domenico de Fiesole: European University Institute.

Fassmann, H., and Munz, R. (1992). Patterns and trends of international migration in western Europe. Popul. Develop. Rev. 18 (3), 457-480. doi: $10.2307 / 1973654$

Finn, V. (2020). Migrant voting: here, there, in both countries, or nowhere. Citizenship Stud. 24 (6), 730-750. doi:10.1080/13621025.2020.1745154

Foweraker, J., and Landman, T. (1999). Individual rights and social movements: a comparative and statistical inquiry. Br. J. Polit. Sci. 29 (2), 291-322. doi:10.1017/ s0007123499000137

Freier, F., and Parent, N. (2018). A South American migration crisis: Venezuelan outflows test neighbors' hospitality. San Domenico de Fiesole: Migration Policy Institute.

Gamlen, A. (2015). The impacts of extra-territorial voting: swings, interregnums and feedback effects in New Zealand elections from 1914 to 2011. Polit. Geogr. 44, 1-8. doi:10.1016/j.polgeo.2014.08.005
Geddes, B. (2005). "Why parties and elections in authoritarian regimes?" in Annual meeting of the American political science association, Washington DC, September 1, 2005, 456-471.

Gleditsch, K. S., and Ward, M. D. (2006). Diffusion and the international context of democratization. Int. Organ. 60 (4), 911-933. doi:10.1017/s0020818306060309

Government of Ireland (2002). Seventh progress report of the all-party committee on the constitution: parliament. Dublin: Stationery Office.

Honohan, I. (2011). Should Irish emigrants have votes? External voting in Ireland. Irish Polit. Stud. 26 (4), 545-561. doi:10.1080/07907184.2011.619749

Huntington, S. P. (1991). Democracy's third wave. J.Democr. 2 (2), 12-34.

Hutcheson, D. S., and Arrighi, J.-T. (2015). "Keeping Pandora's (ballot) box halfshut": a comparative inquiry into the institutional limits of external voting in EU Member States. Democratization 22 (5), 884-905. doi:10.1080/13510347. 2014.979161

Icduygu, A., Sirkeci, I., and Muradoglu, G. (2001). Socio-economic development and international migration: a Turkish study. Int. Migration 39 (4), 39-61. doi:10.1111/1468-2435.00162

Jakobson, M. L., Saarts, T., and Kalev, L. (2020). "Radical right across borders? The case of EKRE's finish branch," in Political parties abroad: a new arena for party politics. Editors T. Kernalegenn and É. Van Haute (Abingdon: Routledge).

Jones-Correa, M. (1998). Between two nations: the political predicament of latinos in New York city. Ithaca: Cornell University Press.

Joppke, C. (2003). Citizenship between de- and Re-ethnicization. Arch. Eur. Sociol. 44 (3), 429-458. doi:10.1017/s0003975603001346

Kayran, E. N., and Erdilmen, M. (2020). When do states give voting rights to noncitizens? The role of population, policy, and politics on the timing of enfranchisement reforms in liberal democracies. J. Ethnic Migration Stud., 1-22. doi:10.1080/1369183x.2020.1782178

Kernalegenn, T., and Van Haute, É. (2020). Political parties abroad: a new arena for party politics. Abingdon: Routledge

Kopstein, J. S., and Reilly, D. A. (2000). Geographic diffusion and the transformation of the post-communist world. World Pol. 53 (1), 1-37. doi:10.1017/s0043887100009369

Lafleur, J.-M. (2015). The enfranchisement of citizens abroad: variations and explanations. Democratization 22 (5), 840-860. doi:10.1080/13510347.2014. 979163

Lafleur, J.-M. (2013). Transnational politics and the state: the external voting rights of diasporas. New York, NY: Routledge.

Linz, J. J., and Stepan, A. C. (1996). Toward consolidated democracies. J. Democracy 7 (2), 14-33. doi:10.1353/jod.1996.0031

Lisi, M., Belchior, A. M., Abrantes, M., and Azevedo, J. (2015). Out of sight, out of mind? External voting and the political representation of Portuguese emigrants. South Eur. Soc. Polit. 20 (2), 265-285. doi:10.1080/13608746.2014.906458

López-Guerra, C. (2005). Should expatriates vote? J. Polit. Philos. 13 (2), 216-234. doi:10.1111/j.1467-9760.2005.00221.x

Lührmann, A., Tannenberg, M., and Lindberg, S. I. (2018). Regimes of the World (RoW): opening new avenues for the comparative study of political regimes. Polit. Governance 6 (1), 60-77. doi:10.17645/pag.v6i1.1214

Magaloni, B. (2006). Voting for autocracy: hegemonic party survival and its demise in Mexico. New York, NY: Cambridge University Press.

Margheritis, A. (2017). The inclusion paradox of enfranchising expats in Latin America. Int. Migr 55 (2), 126-143. doi:10.1111/imig.12315

Minutes of the Grand National Assembly of Turkey (2008). 77th session. Available at: https://www.tbmm.gov.tr/tutanaklar/TUTANAK/TBMM/ d23/c016/tbmm23016077.pdf (Accessed March 23, 2020).

Mudde, C., and Rovira Kaltwasser, C. (2013). Exclusionary vs. inclusionary populism: comparing contemporary Europe and Latin America. Gov. Oppos. 48 (2), 147-174. doi:10.1017/gov.2012.11

Nohlen, F., and Grotz, D. (2000). External voting: legal framework and overview of electoral legislation. Boletín Mexicano de Derecho Comparado 33 (99), 115-146.

Official Gazette of Turkey 26824 (2008a). Act regarding law on basic provisions on elections and electoral roll 5749. Available at: https://www.resmigazete.gov.tr/ eskiler/2008/03/20080322M1-3.htm (Accessed March 22, 2018).

Official Gazette of Turkey 26927 (2008b). Constitutional decision regarding the amendments on the implication of the law on basic provisions on elections and electoral roll. Available at: http://www.resmigazete.gov.tr/eskiler/2008/07/ 20080705-15.htm (Accessed July 05, 2018). 
Østergaard-Nielsen, E., Ciornei, I., and Lafleur, J.-M. (2019). Why do parties support emigrant voting rights? Eur. Pol. Sci. Rev. 11 (3), 377-394. doi:10.1017/ s1755773919000171

Østergaard-Nielsen, E., and Ciornei, I. (2019). Political parties and the transnational mobilisation of the emigrant vote. West Eur. Polit. 42 (3), 618-644. doi:10.1080/01402382.2018.1528105

Østergaard-Nielsen, E. (2003). Transnational politics: the case of Turks and kurds in Germany. Abingdon: Routledge.

Paarlberg, M. A. (2017). Transnational militancy: diaspora influence over electoral activity in Latin America. Comp. Polit. 49 (4), 541-562. doi:10.5129/ 001041517821273053

Palop-García, P., and Pedroza, L. (2019). Passed, regulated, or applied? The different stages of emigrant enfranchisement in Latin America and the Caribbean. Democratization 26 (3), 401-421. doi:10.1080/13510347.2018.1534827

Pérez-Armendariz, C., and Crow, D. (2010). Do migrants remit democracy? International migration, political beliefs, and behavior in Mexico. Comp. Polit. Stud. 43 (1), 119-148. doi:10.1177/0010414009331733

Ramirez, F. O., Soysal, Y., and Shanahan, S. (1997). The changing logic of political citizenship: cross-national acquisition of women's suffrage rights, 1890 to 1990. Am. Sociological Rev. 62 (5), 735-745. doi:10.2307/2657357

Rashkova, E. R. (2020). The party Abroad: a new modus operandi for political parties. Parliamentary Aff. 73 (4), 839-855. doi:10.1093/pa/gsaa039

Rhodes, S., and Harutyunyan, A. (2010). Extending citizenship to emigrants: democratic contestation and a new global norm. Int. Polit. Sci. Rev. 31 (4), 470-493. doi:10.1177/0192512110374044

Rohlfing, I. (2008). What you see and what you get: pitfalls and principles of nested analysis in comparative research. Comp. Polit. Stud. 41 (11), 1492-1514. doi:10. $1177 / 0010414007308019$

R4V (2021). RMRP 2021 For refugees and migrants from VenezuelaRegional Refugee and Migrant Response Plan (January - December 2021). Available at: file://Users/user/Downloads/RMRP\%202021-ENG.pdf.

Saby, R. S. (1918). Absent-voting in Norway. Am. Polit. Sci. Rev. 12 (2), 296-300. doi:10.2307/1943612

Sahhar, G. (2020). Las irregularidades del CNE que generan inseguridad en los electores. Available at El Diario: https:/eldiario.com/2020/08/02/las-irregularidades-del-cneque-generan-inseguridad-en-los-electores/ (Accessed August 12, 2020).

Sahin Mencutek, Z., and Baser, B. (2018). Mobilizing diasporas: insights from Turkey's attempts to reach Turkish citizens abroad. J. Balkan Near East. Stud. 20 (1), 86-105. doi:10.1080/19448953.2017.1375269

Schmid, S. D., Arrighi, J.-T., and Bauböck, R. (2019). ELECLAW indicators: measuring voting and candidacy rights of resident citizens, non-resident citizens and non-citizen residents. San Domenico di Fiesole: European University Institute

Seawright, J., and Gerring, J. (2008). Case selection techniques in case study research: a menu of qualitative and quantitative options. Polit. Res. Q. 61 (2), 294-308. doi:10.1177/1065912907313077

Simpser, A. (2013). Why governments and parties manipulate elections: theory, practice, and implications. New York, NY: Cambridge University Press.

Sirkeci, I., Cohen, J. H., and Yazgan, P. (2012). Turkish culture of migration: flows between Turkey and Germany, socio-economic development and conflict. Migrat. Lett. 9 (1), 33-46. doi:10.33182/ml.v9i1.201
Sirkeci, I. (2005). "Diaspora: Turkish," in Immigration and asylum from 1900 to the present. Editors M. Gibney and R. Hansen (Santa Barbara: ABC-CLIO), 607-610.

Turcu, A., and Urbatsch, R. (2015). Diffusion of diaspora enfranchisement norms: a multinational study. Comp. Polit. Stud. 48 (4), 407-437. doi:10.1177/ 0010414014546331

Turcu, A., and Urbatsch, R. (2020a). European ruling parties' electoral strategies and overseas enfranchisement policies. Eur. J. Polit. Res. 59 (2), 269-289. doi:10. $1111 / 1475-6765.12357$

Turcu, A., and Urbatsch, R. (2020b). Go means green: diasporas' affinity for ecological groups. Glob. Environ. Polit. 20 (1), 82-102. doi:10.1162/glep_a_00538

Umpierrez de Reguero, S., and Dandoy, R. (2021). Should we go abroad? The strategic entry of Ecuadorian political parties in overseas electoral districts. Representation: Journal of Representative Democracy. doi:10. 1080/00344893.2021.1902850

Umpierrez de Reguero, S., and Dandoy, R. (2020). "Extending the incumbency presence abroad," in Political parties abroad: a new arena for party politics. Editors T. Kernalegenn and É. Van Haute (Abingdon: Routledge).

Umpierrez de Reguero, S., Finn, V., Cartagena, V., and Baquerizo, G. (2020). El sufragio multiterritorial: evidencia de migrantes andinos en Ecuador [multiterritorial suffrage: evidence from andean migrants in Ecuador]. Revista Andina de Estudios Politicos 10 (1), 126-151. doi:10.35004/raep. v10i1.187

Verdery, K. (1998). Transnationalism, nationalism, citizenship, and property: eastern Europe since 1989. Am. Ethnol. 25 (2), 291-306. doi:10.1525/ae.1998.25.2.291

Wellman, E. I. (2020). Emigrant inclusion in home country elections: theory and evidence from sub-saharan Africa. Am. Polit. Sci. Rev. 115 (1), 82-96. doi:10. 1017/s0003055420000866

Yanasmayan, Z., and Kaşl1, Z. (2019). Reading diasporic engagements through the lens of citizenship: Turkey as a test case. Polit. Geogr. 70, 24-33. doi:10.1016/j. polgeo.2019.01.004

Yener-Roderburg, I. Ö. (2020). "Party organizations across borders: top-down satellites and bottom-up alliances. The case of AKP and HDP in Germany," in Political parties abroad: a new arena for party politics. Editors T. Kernalegenn and É. Van Haute (Abingdon: Routledge).

YSK (2020). Election results between 1987-2018. Available at: https://sonuc.ysk. gov.tr/sorgu (Accessed January 17, 2020).

Conflict of Interest: The authors declare that the research was conducted in the absence of any commercial or financial relationships that could be construed as a potential conflict of interest.

Copyright (c) 2021 Umpierrez de Reguero, Yener-Roderburg and Cartagena. This is an open-access article distributed under the terms of the Creative Commons Attribution License (CC BY). The use, distribution or reproduction in other forums is permitted, provided the original author(s) and the copyright owner(s) are credited and that the original publication in this journal is cited, in accordance with accepted academic practice. No use, distribution or reproduction is permitted which does not comply with these terms. 